\author{
ALEKSANDRA BERNATOWICZ \\ Uniwersytet Warszawski
}

\title{
ZAKRES OCHRONY NAZWISKA JAKO ZNAKU TOWAROWEGO WZGLĘDEM INTERESU POWSZECHNEGO W PRAWIE UNII EUROPEJSKIEJ
}

\begin{abstract}
Abstrakt: Nazwisko jest częstym przedmiotem rejestracji jako znak towarowy. Wraz z rejestracją nazwiska jako znaku uprawniony podmiot zyskuje co do zasady prawo wyłączności jego używania $\mathrm{w}$ obrocie handlowym. Jednocześnie jednak nazwisko jest elementem domeny publicznej, która wyraża interes powszechny w prawie znaków towarowych. Ochrona domeny publicznej jest jednym z istotnych i współczesnych problemów w prawie znaków towarowych Unii Europejskiej. Konieczność adekwatnego zabezpieczenia interesu powszechnego postuluje między innymi Światowa Organizacja Własności Intelektualnej. Ustawodawca unijny przyjął wprawdzie szeroki model ochrony domeny publicznej. Nadal jednak można wskazać praktyczne przykłady niewystarczającej ochrony interesu powszechnego względem szerokiego zakresu uprawnień właściciela znaku. Jednym z nich jest właśnie rejestracja znaku towarowego obejmującego nazwisko. Artykuł ma na celu podkreślenie konieczności adekwatnego zabezpieczenia interesu powszechnego $\mathrm{w}$ ramach rejestracji nazwisk, a także ocenę regulacji przyjętej w tym zakresie w prawie Unii Europejskiej.
\end{abstract}

Słowa kluczowe: znaki towarowe, domena publiczna, unijne prawo znaków towarowych, znaki rodzajowe, znaki-nazwiska

\section{WPROWADZENIE}

Znaki towarowe zastrzegające nazwisko stanowią chętnie wybierany przedmiot rejestracji. W końcu nazwisko w najlepszy sposób połączy oferowany towar $\mathrm{z}$ jego producentem. Znakowanie towarów lub usług własnym nazwiskiem jest też efektywnym sposobem budowania marki, także dla przyszłych pokoleń. $\mathrm{Na}$ rynku można spotkać szereg towarów oznaczonych nazwiskami - Guiness, Bailey's, Michelin, Kärcher, Dyson, Ford, Dell, McDonald's itp. Widząc te nazwiska, przeciętny odbiorca utożsamia je od razu z konkretnym towarem lub usługą choć często nie zdaje sobie sprawy z pochodzenia samej nazwy. Szczególna pod tym względem jest branża modowa, w której imiona i nazwiska projektantów stały się nazwami poszczególnych domów mody. $\mathrm{Z}$ czasem nazwiska rejestrowano jako znaki towarowe, które dziś są markami znanymi na całym świecie. 
Kluczowy problem z rejestracją znaków w postaci nazwiska polega na relatywnie dużym prawdopodobieństwie istnienia identycznego znaku w obrocie, choć niekoniecznie zarejestrowanego. W 2012 roku Światowa Organizacja Własności Intelektualnej przygotowała raport zawierający analizę różnych mechanizmów ochrony domeny publicznej w prawie znaków towarowych ${ }^{1}$. We wstępie analizy podkreślono specyfikę ochrony znaków towarowych względem chociażby patentów - raz zarejestrowany znak towarowy może w praktyce nigdy nie powrócić do domeny publicznej. Wystarczy, aby używanie znaku było kontynuowane, a rejestracja przedłużana ${ }^{2}$. Z drugiej strony źródłem znaku jest często domena publiczna. Znaki mogą być i są przecież konstruowane wyłącznie ze słów lub symboli już istniejących. $Z$ domeny publicznej pochodzą właśnie nazwiska. W ramach poszczególnych porządków prawnych przyjęto różne rozwiązania mające zabezpieczyć interes znaków powszechnych przy jednoczesnej ochronie zarejestrowanych.

W literaturze wskazuje się, że prawo znaków towarowych Unii Europejskiej zapewnia szeroką, wręcz modelową, ochronę domeny publicznej ${ }^{3}$. Należy się zgodzić z twierdzeniem, że ustawodawca unijny w znacznym stopniu uwzględnił bezpieczeństwo domeny publicznej. W systemie prawnym Unii Europejskiej wprowadzono pewne mechanizmy ochrony domeny publicznej przed nieuzasadnionymi rejestracjami. Można wyróżnić cztery rodzaje metod ochrony domeny publicznej w ramach znaków towarowych:

— automatyczne wyłączenie z ochrony;

— wyłączenie ze względu na brak zdolności odróżniającej;

- ograniczenie zakresu ochrony;

— wprowadzenie wyjątków w ramach ochrony.

Odnośnie do rejestracji nazwisk nie przewidziano jednak żadnego dodatkowego obostrzenia. Można zarejestrować nazwisko jako znak, jeżeli spełnia ono zaledwie dwie przesłanki wymagane względem wszystkich zgłoszeń — cechuje się zdolnością odróżniającą i można je przedstawić w rejestrze ${ }^{4}$. W praktyce każde nazwisko może spełnić oba te wymogi. Nazwisko ze swej istoty jest oznaczeniem konkretnej osoby fizycznej i ma na celu odróżnienie jej od innych. Nie ma też wątpliwości, że jest to oznaczenie słowne, możliwe do przedstawienia w rejestrze $\mathrm{w}$ formie słownej lub słowno-graficznej.

1 Dokument nr CDIP/9/INF/5, Study on Misappropriation of Signs, red. M. Seftleben, http:// www.wipo.int/edocs/mdocs/mdocs/en/cdip_9/cdip_9_inf_5.pdf (dostęp: 13.11.2021).

2 Ibidem, s. 9.

3 M. Senftleben, Public Domain Preservation in EU Trademark Law - A Model for Other Regions?, „The Trademark Reporter” 2013, nr 4.

${ }^{4}$ Odpowiednio art. 3 dyrektywy Parlamentu Europejskiego i Rady 2015/2436 z dnia 16 grudnia 2015 roku i art. 4 rozporządzenia Parlamentu Europejskiego i Rady 2017/1001 z dnia 14 czerwca 2017 roku. 
W rezultacie można wskazać przykłady sytuacji, w których właściciele znaków-nazwisk w sposób zgodny z prawem korzystają z ochrony, ale kosztem powszechnego dostępu do nazwiska. Podmiot z zarejestrowanym znakiem-nazwiskiem będzie mógł co do zasady zakazać używania nazwiska innym osobom w obrocie gospodarczym z wyjątkiem opisanym w dalszej części. Komercyjne użycie nazwiska zostaje wyłączone wskutek rejestracji. Dodatkowym czynnikiem ograniczającym ochronę interesu powszechnego jest rozszerzona ochrona przyznana znakom renomowanym. Brak szczególnego podejścia do nazwiska jako przedmiotu rejestracji może więc doprowadzić do sytuacji, w której zmonopolizowany zostanie element domeny publicznej. Jest to zjawisko negatywne, któremu należy przeciwdziałać.

Celem artykułu jest rozważenie, czy ochrona interesu powszechnego przewidziana w prawie Unii Europejskiej jest wystarczająca w ramach rejestracji nazwisk jako znaków towarowych. Innymi słowy, należy odpowiedzieć na pytanie, czy ustawodawca unijny może skorzystać z dodatkowych mechanizmów, silniej uwzględniających interes powszechny. Podstawą rozważań będzie analiza obowiązującego w Unii Europejskiej prawa znaków towarowych w zakresie rejestracji nazwisk, a także odwołanie się do jego wykładni przyjętej w praktyce orzeczniczej. Punktem wyjścia do dalszych wywodów będzie krótkie przedstawienie stanu faktycznego, który stał się inspiracją do podjęcia rozważań w tym zakresie. W ramach dalszego wywodu wzmiankowana zostanie także rozszerzona ochrona znaków renomowanych z uwagi na częste istnienie renomy znaków-nazwisk. Wnioski wyciągnięte $\mathrm{z}$ tak zakreślonego badania zostaną przedstawione na końcu wywodu.

\section{SPRAWA HUGO BOSS I BOSS BREWING}

W sierpniu 2019 roku brytyjskie Intellectual Property Office otrzymało wniosek złożony przez rzemieślniczy walijski browar o nazwie Boss Brewing o zarejestrowanie między innymi dwóch napojów będących piwami o nazwach BOSS BLACK i BOSS BOSS. Zgłoszenie rejestracyjne miało objąć 32, 33 i 43 klasę nicejską, zatem ujmując szeroko - napoje alkoholowe i usługi restauracyjne. Browar funkcjonował na rynku od 2014 roku, był wielokrotnie nagradzany, zaś od 2018 roku nazwa Boss Brewing była zarejestrowana jako znak towarowy w Wielkiej Brytanii. Zamiast pozytywnej decyzji IPO, browar otrzymał tak zwany cease and desist letter (wezwanie do zaprzestania naruszeń) od modowego giganta Hugo Boss ${ }^{5}$, który był już właścicielem dwóch znaków zarejestrowanych

5 Welsh brewery changes name of beers after trademark battle with Hugo Boss, thedrinksbusiness.com (dostęp: 2.03.2020). 
przez EUIPO — BOSS Black ${ }^{6}$ i BOSS HUGO BOSS ${ }^{7}$. Oba zarejestrowane znaki obejmowały jednak inne klasy nicejskie — 3, 18, 24, 25, 28. W wyniku negocjacji Boss Brewing zmienił nazwy trunków na Boss Brewing Black i Boss Bossy. Browar poniósł jednak ogromne koszty związane z obsługą prawną i koniecznością znakowania towarów na nowo ${ }^{8}$.

Sprawa Boss Brewing zyskała rozgłos w wyniku działania znanego brytyjskiego komika. Joe Lycett uznał, że działania Hugo Boss były nieadekwatne względem ekonomicznej pozycji Boss Brewing. W akcie protestu zmienił swoje imię i nazwisko na Hugo Boss ${ }^{9}$. Akcja komika miała pokazać, że dom modowy Hugo Boss nie ma monopolu na sam wyraz boss. O ile wystąpienie Lycetta miało charakter prześmiewczy i zostało podjęte w geście solidarności z lokalnym przedsiębiorcą, o tyle $\mathrm{z}$ punktu widzenia prawa znaków towarowych nie było pozbawione racji.

Znak towarowy powinien być każdorazowo otoczony ochroną wtedy, gdy naruszona zostaje jedna z jego funkcji. W przypadku znaków renomowanych, do jakich niewątpliwie należy zaliczyć znaki zarejestrowane na rzecz firmy Hugo Boss, ochrona ta jest rozszerzona, co zostanie przedstawione bardziej precyzyjnie w dalszej części artykułu. Rozszerzony zakres ochrony nie może jednak oznaczać praktycznego zmonopolizowania nazwy w obrocie gospodarczym. Naruszenie prawa do znaku renomowanego musi nadal polegać na bezzasadnym zaburzeniu jednej z jego funkcji, przy czym względem znaków renomowanych ustawodawca unijny zakłada apriorycznie silniejsze oddziaływanie funkcji odróżniającej i jakościowej, a w konsekwencji — potrzebę ich wzmożonej ochrony. Właściciel znaku musi więc wykazać, że z bezprawnego używania tego ostatniego, osoba trzecia czerpie nienależną korzyść z charakteru odróżniającego lub z renomy owego znaku lub działa na szkodę tego charakteru lub renomy ${ }^{10}$.

W przywołanej sprawie właściciel znaku skorzystał z niezwykle szerokiej ochrony, omijając ustalenie negatywnego zachowania podmiotu naruszającego. Biorąc pod uwagę, że naruszony znak wywodził się z domeny publicznej, sprawa może budzić pewne zastrzeżenia. Powstaje jednocześnie pytanie, czy obowiązujące w Unii Europejskiej prawo znaków towarowych chroni znaki-nazwiska, uwzględniając należycie interes publiczny.

6 Zgłoszenie nr 003405149.

7 Zgłoszenie nr 002860377.

8 Fashion giant Hugo Boss takes on Boss Brewing in Wales over its name, https://www. walesonline.co.uk (dostęp: 13.04.2020).

9 Comedian Joe Lycett changes name to Hugo Boss in swipe at fashion house, „The Guardian” (dostęp: 2.03.2020).

10 Wyrok TSUE z dnia 11 kwietnia 2019 roku w sprawie C-690/17 ÖKO-Test Verlag GmbH, pkt 45, ECLI:EU:C:2019:317. 


\section{ZDOLNOŚĆ ODRÓŻNIAJĄCA NAZWISKA JAKO ZNAKU TOWAROWEGO}

Ujmując najprościej, charakter odróżniający znaku towarowego polega na ocenie, czy odbiorca jest w stanie odróżnić oznaczone towary lub usługi od tych o innym pochodzeniu handlowym. Oceny dokonuje się z perspektywy przeciętnego konsumenta towaru lub usługi przy założeniu, że jest to podmiot właściwie poinformowany, dostatecznie uważny i rozsądny ${ }^{11}$.

W prawie Unii Europejskiej nazwisko może być przedmiotem rejestracji bez żadnych dodatkowych (względem innych oznaczeń) obostrzeń. Nazwisko nie zostało uznane za oznaczenie rodzajowe, a wręcz wskazano je jako przykład przedmiotu rejestracji (w art. 3 dyrektywy 2015/2436, zaś dla znaków unijnych w art. 4 rozporządzenia 2017/1001). Ustawodawca unijny nie zdecydował więc, że interes powszechny miałby uzasadniać pozbawienie nazwiska zdolności rejestracyjnej.

Dla porównania w Stanach Zjednoczonych rejestracja nazwiska jako znaku towarowego jest obwarowana dodatkową przesłanką. W $§ 1052$ lit. e pkt 4 Lanham $\mathrm{Act}^{12}$ uniemożliwiono rejestrację oznaczenia będącego ,tylko nazwiskiem” (merely a surname). Niezbędne jest wykazanie, że nazwisko zyskało odpowiedni poziom zdolności odróżniającej, nadający mu odrębne znaczenie w obrocie ${ }^{13}$. Zdolność odróżniająca nazwiska musi więc zyskać kwalifikowany poziom w porównaniu $\mathrm{z}$ innymi oznaczeniami. $\mathrm{Z}$ góry zakłada się więc, że samo nazwisko ma słabą zdolność odróżniającą, choć możliwe jest jej wzmocnienie poprzez funkcjonowanie na rynku. Na przestrzeni lat praktyka Trademark Trial and Appeal Board wykształciła pewne kryteria pomocne w ustalaniu, czy nazwisko nadaje się do rejestracji jako znak (rzadkość występowania ${ }^{14}$, związek nazwiska z podmiotem zgłaszającym do rejestracji ${ }^{15}$, istniejące inne znaczenie nazwiska ${ }^{16}$ ). W decyzji Miller $v$. Miller odwrócono badanie zdolności rejestracyjnej nazwiska poprzez postawienie pytania, czy odbiorcy postrzegają znak wyłącznie jako nazwisko. Istotne jest więc, czy nazwisko stało się na tyle rozpoznawalne w obrocie handlowym, że wykroczyło poza swoją pierwotną rolę identyfikacji osoby fizycznej ${ }^{17}$.

11 Tak na przykład wyroki TSUE z dnia 18 czerwca 2002 roku w sprawie C-299/99 Philips, pkt 47-48, ECLI:EU:C:2002:377, z dnia 4 maja 1999 roku w sprawach połączonych C-108/97 i C-109/97 Windsurfing Chiemsee, pkt 29, ECLI:EU:C:1999:230.

12 Lanham Trade-Mark Act of 1946, 50 Stat. 427 (Jul. 5, 1946), skodyfikowany, z poprawkami, w 15 U.S.C. 1051 et seq.

13 J.C. Ginsburg, Trademark and Unfair Competition Law: Cases and Materials, Durham 2007, s. 80.

14 Benthin Mgmt. GmbH, 37 USPQ2d 1332, 1333 (TTAB 1995).

15 Etablissements Darty et Fils, 759 F.2d 15, 17, 225 USPQ 652, 653 (Fed. Cir. 1985).

16 Eximius Coffee, 120 USPQ2d 1276, 1280 (TTAB 2016).

17 Decyzja Trademark Trial and Appeal Board Proceedings Miller v. Miller, 105 USPQ2d 1615. 
Skoro jednak w prawie Unii Europejskiej nie wprowadzono żadnych dodatkowych obostrzeń zdolności rejestracyjnej względem nazwisk, w praktyce pojawił się problem sprzecznych interesów - prywatnego i powszechnego. Pewne wątpliwości interpretacyjne w zakresie znaków-nazwisk zostały doprecyzowane w orzecznictwie Trybunału Sprawiedliwości.

\section{ZDOLNOŚĆ REJESTRACYJNA NAZWISKA}

Podstawowym orzeczeniem dotykającym zagadnienia zdolności rejestracyjnej nazwiska jest wyrok w sprawie Nichols ${ }^{18}$. W maju 2000 roku dyrektor brytyjskiego urzędu rejestracji znaków towarowych, Registrat of Trade Marks, opublikował okólnik (Practice Amendment Circular, nr 6/00), w którym z góry określono, jakie okoliczności należy uwzględnić, oceniając charakter odróżniający nazwiska lub imienia zgłoszonego jako znak towarowy. Wskazano, że elementami podlegającymi uwzględnieniu są między innymi popularność nazwiska lub liczba przedsiębiorstw działających w branży, w której występują towary oznaczone nazwiskiem. W dalszej części dokumentu wskazano, że za popularne uznać należy nazwisko występujące częściej niż 200 razy w londyńskiej lub innej stosownej książce telefonicznej.

W świetle ustalonej praktyki urząd oddalił wniosek Nichols plc o rejestrację tytułowego nazwiska w części obejmującej oznaczenie produktów spożywczych i napojów. Urząd uznał, że nazwisko Nichols — zapisywane w różnych odmianach, także jako „Nicholls” lub „Nichol” — jest na tyle popularne w Zjednoczonym Królestwie, że nie może służyć do oznaczenia towarów obejmujących znaczny rynek zbytu. Popularność nazwiska Nichols została przez Urząd ustalona na podstawie częstotliwości jego występowania w książce telefonicznej. Mało prawdopodobne byłoby więc uznanie przez konsumentów, że w całym kraju działa jeden przedsiębiorca o nazwisku Nichols oferujący produkty spożywcze. Względem produktów spożywczych i napojów nazwisko Nichols jest pozbawione zdolności odróżniającej. Jednocześnie jednak zarejestrowano znak dla automatów sprzedających produkty spożywcze. Urząd brytyjski uzależnił więc niejako zdolność rejestracyjną nazwiska od specyfiki rynku, na którym występują oznaczone towary. Jeżeli na rynku działa mniej przedsiębiorców, to nawet popularne nazwisko ma zdolność rejestracyjną

Po wniesieniu odwołania przez zgłaszającego sąd krajowy zauważył, że zagadnienie zdolności odróżniającej popularnego nazwiska rodzi pewne problemy interpretacyjne. W ocenie sądu brytyjskiego należało ustalić, czy rejestrację popularnego nazwiska należy uzależnić od uzyskania charakteru odróżniającego w następstwie jego używania.

18 Wyrok TSUE z dnia 16 września 2004 roku, C-404/02 Nichols, ECLI:EU:C:2004:538. 
Sąd krajowy wskazał też, że jeżeli ograniczenie skutku rejestracji znaku w postaci uprawnienia „strony trzeciej” do używania zarejestrowanego nazwiska będzie wykładane szeroko, to charakter odróżniający będzie mniej istotny. Pytania sądu krajowego zmierzały do ustalenia dwóch elementów. Po pierwsze, jakie wymogi należy uwzględnić, badając charakter odróżniający nazwiska, zwłaszcza popularnego, oraz po drugie, czy wpływ na te wymogi ma ograniczenie skutku rejestracji znaku wyrażone art. 6 ust. 1 lit. a dyrektywy 89/104 ${ }^{19}$.

Trybunał podkreślił przede wszystkim, że ustawodawca unijny w art. 2 dyrektywy $89 / 104^{20}$ wymienił nazwisko wśród przykładowych oznaczeń podlegających rejestracji. Z kolei charakter odróżniający badany jest dla każdego oznaczenia $\mathrm{w}$ ten sam sposób, z perspektywy konsumenta zainteresowanego towarem. Państwa członkowskie nie mogą wprowadzać samodzielnie dodatkowych, bardziej surowych kryteriów oceny charakteru odróżniającego. Przykładowo nie można uwzględniać z góry ustalonego progu, powyżej którego nazwisko byłoby pozbawione charakteru odróżniającego, liczby przedsiębiorstw dostarczających towary tej samej kategorii, powszechnego użycia nazwiska w danej branży. Ocena charakteru odróżniającego musi być dokonywana indywidualnie dla każdego oznaczenia. Nie mogą istnieć w tym zakresie kryteria ustalone generalnie dla pewnej kategorii. Wykluczone jest odgórne założenie, że samo oznaczenie jest pozbawione charakteru odróżniającego lub musi je nabyć w procesie używania. Trybunał posłużył się przede wszystkim wykładnią literalną, podkreślając brak stosownych obostrzeń w przepisach dyrektywy.

Dla oceny charakteru odróżniającego nie ma też znaczenia ograniczenie skutku rejestracji polegające na dalszej możliwości używania własnego nazwiska w obrocie handlowym, pomimo jego rejestracji na rzecz innego podmiotu. Ocena ta nadal powinna mieć charakter konkretny i zindywidualizowany. Nie można wprowadzać automatycznych rozstrzygnięć dla szerszej kategorii oznaczeń.

Sąd krajowy zadał również pytanie o możliwość rozszerzenia na nazwę przedsiębiorstwa ograniczenia skutku rejestracji wyrażonego w art. 6 ust. 1 lit. a dyrektywy 89/104. Skoro jednak Trybunał uznał, że przepis ten jest nieistotny z punktu widzenia oceny charakteru odróżniającego, to na pytanie nie odpowiedział. Do kwestii tej Trybunał odniósł się w wyroku w sprawie Anheuser-Busch ${ }^{21}$. W treści orzeczenia uznano, że art. 6 ust. 1 lit. a dyrektywy 89/104 nie ogranicza się tylko do nazwisk osób fizycznych.

$\mathrm{Z}$ wywodów Trybunału wynika więc jedynie to, że nie jest możliwe stosowanie z góry dodatkowych obostrzeń względem oznaczeń złożonych z nazwisk. Jednocześnie jednak Trybunał nie stwierdził, że kryteria zastosowane przez brytyjski urząd rejestracji były niewłaściwe. Istotne jest tylko ograniczenie automatyzmu

19 Obecnie art. 14 ust. 1 lit. a dyrektywy 2015/2436.

20 Obecnie art. 3 dyrektywy 2015/2436.

21 Wyrok TSUE z dnia 16 listopada 2004 roku w sprawie C-245/02 Anheuser-Busch, ECLI:EU:C:2004:717. 
w ich stosowaniu. W opinii rzecznika generalnego wskazano nieco bardziej stanowczo, że elementy takie jak charakter oznaczonego towaru lub odbiór konsumenta są przydatne dla oceny charakteru odróżniającego znaku ${ }^{22}$.

W świetle wyroku w sprawie Nichols zdolność odróżniająca nazwiska zależy więc wyłącznie od tego, czy przeciętny konsument jest w stanie odróżnić towary nim oznaczone od tych o innym pochodzeniu handlowym. Czynniki, jakimi posłużył się urząd brytyjski, mogą w konkretnej sprawie być wzięte pod uwagę w procesie badania charakteru odróżniającego.

\section{KONTRUPRAWNIENIE OSOBY TRZECIEJ}

Zarówno w ramach reżimu znaków unijnych, jak i zharmonizowanej regulacji znaków krajowych ustawodawca unijny przewidział kontruprawnienie osoby trzeciej. Zgodnie z art. 14 ust. 1 lit. a i ust. 2 dyrektywy 2015/2436 oraz art. 14 ust. 1 lit. a i ust. 2 rozporządzenia 2017/1001 z uprawnień właściciela znaku wyłączono możliwość zakazu używania nazwiska przez osobę trzecią, jeżeli jest to osoba fizyczna. $Z$ tym jednak zastrzeżeniem, że używanie znaku przez osobę trzecią musi być zgodne z uczciwymi praktykami w przemyśle i handlu.

Tego rodzaju ograniczenie stanowi uwzględnienie prawa osoby fizycznej do komercyjnego użytku własnego nazwiska ${ }^{23}$. Tożsame kontruprawnienie nie zostało przyznane wprost jednostkom organizacyjnym względem ich nazw. W orzecznictwie Trybunału rozszerzono jednak pojęcie „nazwiska” na nazwę osoby prawnej lub jakiekolwiek inne oznaczenie odróżniające traktowane jako nazwa handlowa ${ }^{24}$.

W wyroku w sprawie Céline ${ }^{25}$ Trybunał dokonał wykładni opisanego powyżej ograniczenia skutku rejestracji względem osoby trzeciej. W sprawie doszło do sporu dwóch spółek, które w różny sposób w obrocie handlowym używały tego samego nazwiska. W 1928 roku zarejestrowana została Céline SA, spółka wytwarzająca i sprzedająca artykuły ubraniowe i dodatki odzieżowe. Céline SA zgłosiła do rejestracji znak słowny CÉLINE obejmujący przede wszystkim odzież i obuwie. Od 1950 roku w Nancy, pod szyldem Céline, działał sklep odzieżowy Adriena Grynfogela. Od 1992 roku prawo do używania szyldu Céline przejęła spółka Céline SARL. Céline SA wystąpiła następnie przeciwko Céline SARL z powództwem o zaprzestanie naruszania prawa do znaku towarowego CÉLINE.

22 Opinia rzecznika generalnego Dámasa Ruiza-Jaraba Colomera przedstawiona w dniu 15 stycznia 2004 roku do wyroku w sprawie C-404/02 Nichols.

23 U. Promińska, Wprowadzenie do prawa własności przemystowej, [w:] A. Nowicka et al., Prawo własności przemysłowej, red. U. Promińska, Warszawa 2005, s. 250.

24 Tak między innymi wyrok TSUE w sprawie Anheuser-Busch, ibidem, pkt 77-80.

25 Wyrok TSUE z dnia 11 września 2017 roku w sprawie C-17/06 Céline, ECLI:EU:C:2007:497. 
Rozpoznający sprawę sąd francuski uwzględnił powództwo w całości i zakazał Céline SARL używania znaku CÉLINE. W odwołaniu od wyroku strona pozwana wskazała, że do naruszenia nie doszło. Szyld nie miał służyć do odróżnienia oferowanych towarów. Nie mogło też dojść do wprowadzenia w błąd ze względu na luksusowy charakter towarów Céline SA. Udzielając odpowiedzi na pytanie zadane przez sąd krajowy, Trybunał rozważył, czy oznaczenie przedsiębiorstwa nazwiskiem Céline dopiero po jego rejestracji na rzecz innego podmiotu, jest używaniem zgodnym z uczciwymi praktykami w handlu i przemyśle. Odwołując się do wcześniejszego orzecznictwa ${ }^{26}$, Trybunał wskazał, że użycie znaku jest niezgodne z uczciwymi praktykami w handlu i przemyśle zwłaszcza wtedy, gdy:

- jest dokonywane w taki sposób, że może sprawiać wrażenie istnienia powiązań gospodarczych między osobą trzecią a właścicielem znaku towarowego;

— narusza wartość znaku towarowego poprzez osiąganie nieuzasadnionych korzyści wynikających z jego charakteru odróżniającego albo renomy;

— prowadzi do dyskredytacji lub oczerniania znaku.

$Z$ rozumowania Trybunału należy więc wyciągnąć wniosek, że nieuczciwe będzie użycie znaku o cechach pasożytniczych. Jeżeli osoba trzecia działa w celu ograniczenia funkcji cudzego znaku z korzyścią dla siebie, to nie będzie przysługiwać jej kontruprawnienie ograniczające zakres cudzego znaku. Przewidziane przez ustawodawcę unijnego kontruprawnienie osoby noszącej zarejestrowane nazwisko jest skutecznym narzędziem ochrony przed szerokim zakresem uprawnień właściciela znaku. Do naruszenia prawa ochronnego nie dojdzie, jeżeli nie zostanie wykazane bezprawne użycie cudzego znaku. O bezprawności nie będzie zaś można mówić, jeżeli użycie znaku będzie uczciwe w rozumieniu przedstawionym powyżej.

\section{ZNAKI RENOMOWANE}

Nazwiska od zawsze były chętnie wybierane przez przedsiębiorców jako oznaczenia w obrocie handlowym. Rezultatem dużej częstotliwości rejestracji jest większy odsetek znaków renomowanych w tej grupie. To z kolei powoduje, że część znaków-nazwisk jest chroniona w sposób rozszerzony.

Przyznanie rozszerzonej ochrony znakom renomowanym ma na celu ochronę przed „osłabieniem” ich odbioru ${ }^{27}$. Znak renomowany jest pojęciem niezdefiniowanym legalnie w prawie unijnym. W praktyce orzeczniczej TSUE identyfikacja znaku renomowanego opiera się na założeniu szerszej niż normalnie znajomo-

26 Wyrok TSUE z dnia 17 marca 2005 roku w sprawie C-228/03 Gillette, ECLI:EU:C:2005:177.

27 Opinia rzeczniczki generalnej Eleanor Sharpston z dnia 26 czerwca 2008 roku przedstawiona na potrzeby wyroku TSUE z dnia 27 listopada 2008 roku w sprawie C-252/07 Intel, pkt 1, ECLI:EU:C:2008:370. 
ści wśród odbiorców. Przyjmuje się istnienie pewnego poziomu wiedzy o znaku wśród przeważającej części odbiorców zainteresowanych określonym towarem ${ }^{28}$. Orzecznictwo TSUE dostarcza szerokiego katalogu okoliczności, które powinno się brać pod uwagę w procesie badania renomy znaku: udział znaku towarowego w rynku, natężenie, zasięg geograficzny i długość okresu jego używania oraz wielkość inwestycji dokonanych przez przedsiębiorstwo w celu promocji znaku ${ }^{29}$. Przy czym ekskluzywny charakter marki nie zawsze będzie równoznaczny z renomą znaku towarowego. Przeciwnie - ekskluzywność powoduje jakościową zmianę w kręgu odbiorców towaru. Zakłada się, że w konsekwencji zawężenia kręgu potencjalnych odbiorców, są oni bardziej zainteresowani, a jednocześnie lepiej poinformowani o towarach dostępnych na rynku ${ }^{30}$.

Uznanie, że znak towarowy jest renomowany, stanowi punkt wyjścia do zbadania tego, czy ziściły się przesłanki rozszerzonej ochrony przeciwko naruszeniom. W prawie Unii Europejskiej względem znaków renomowanych zrezygnowano z wymogu identyczności lub podobieństwa znakowanych towarów, ale jedynie w sytuacji, gdy osoba używająca znaku odnosi z tego tytułu nienależną korzyść $\mathrm{z}$ racji odróżniającego charakteru lub renomy znaku towarowego lub gdy jest to szkodliwe dla tego charakteru lub renomy. Stanowi o tym wprost art. 9 ust. 2 lit. c rozporządzenia 2017/1001 i art. 5 ust. 3 lit. a dyrektywy 2015/2436.

Ochrona znaków renomowanych jest rozszerzona, jednak nie może prowadzić do całkowitego wyłączenia czynnika percepcji odbiorcy znaku. Nie wymaga się wprawdzie zaistnienia identyczności pomiędzy znakami albo podobieństwa powodującego ryzyko w prowadzenia w błąd. Nadal trzeba jednak ustalić podobieństwo znaku naruszającego do znaku renomowanego w stopniu uzasadniającym powstanie ryzyka skojarzenia obu znaków ${ }^{31}$. Ryzyko skojarzenia jest jednak kategorią słabszą niż ryzyko wprowadzenia w błąd. Nie wymaga się wykazania możliwości pomylenia znaków przez odbiorców. Wystarczy samo niebezpieczeństwo powstania związku pomiędzy znakami w świadomości odbiorcy.

Ocena zaistnienia ryzyka skojarzenia znaków będzie przebiegać w nieco inny sposób. Nadal musi być to badanie kompleksowe, uwzględniające szereg czynników, przy czym szczególną uwagę należy zwrócić na: stopień podobieństwa między kolidującymi ze sobą znakami; charakter towarów lub usług, dla których kolidujące ze sobą znaki zostały zarejestrowane, w tym stopień pokrewności i różnic między tymi towarami lub usługami oraz dany krąg odbiorców; intensywność używania i renomę wcześniejszego znaku towarowego; stopień samoistnego lub

28 Tak też TSUE w wyroku z dnia 14 września 1999 roku w sprawie C-375/97 General Motors, pkt 17, ECLI:EU:C:1999:408.

${ }^{29}$ Wyrok TSUE z dnia 27 listopada 2008 roku w sprawie C-252/07 Intel, ECLI:EU:C:2008:655.

30 Tak też WSA w Warszawie w wyroku z dnia 30 sierpnia 2010 roku, sygn. akt VI SA/Wa $807 / 10$.

31 Wyrok TSUE z dnia 23 października 2003 roku w sprawie C-408/01 Adidas-Salomon, ECLI:EU:C:2003:582, pkt 29-31. 
uzyskanego w następstwie używania charakteru odróżniającego wcześniejszego znaku towarowego; istnienie prawdopodobieństwa wprowadzenia odbiorców w błąd ${ }^{32}$.

W ramach ochrony renomowanych znaków-nazwisk należy jednak dodatkowo uwzględnić kontruprawnienie osoby trzeciej. Przepisy unijne nie regulują w żaden sposób relacji pomiędzy rozszerzoną ochroną znaków renomowanych, a kontruprawnieniem osoby trzeciej, która ją zawęża. Jest to przy tym kwestia istotna z praktycznego punktu widzenia. Ryzyko skojarzenia będące przesłanką naruszenia prawa do znaku renomowanego nie uwzględnia elementu subiektywnego w postaci zamiaru podmiotu naruszającego. Kontruprawnienie osoby trzeciej jest zaś oparte o ocenę zachowania przez pryzmat uczciwości, a mówiąc ściślej dobrej wiary. $Z$ tego powodu nie jest możliwe jednoczesne rozszerzenie ochrony znaku renomowanego i jej zawężenie poprzez uwzględnienie uprawnienia osoby trzeciej.

Dokonując wykładni systemowej obu przepisów, trzeba przyjąć, że użycie własnego nazwiska przez osobę trzecią w dobrej wierze nie powinno zostać ograniczone, nawet w przypadku znaków renomowanych. Nie można zapominać, że nazwisko wchodzi w skład domeny publicznej. Decydując się na dokonanie rejestracji, właściciel znaku musi liczyć się z możliwością istnienia jednakowego oznaczenia powiązanego z inną osobą. Rejestracja na rzecz jednego podmiotu nie może automatycznie pozbawić innych osób noszących identyczne nazwisko możliwości korzystania z niego w ramach działalności komercyjnej. Granicą komercyjnego użycia nazwiska przez inną osobę jest zaś jej dobra wiara. Tak interpretowany zakres ochrony znaku renomowanego zastrzegającego nazwisko jest adekwatnym zabezpieczeniem interesu publicznego. Korzystne byłoby jednak uregulowanie tej kwestii wprost w przepisach dyrektywy i rozporządzenia.

\section{OCENA OBOWIĄZUJĄCEGO STANU PRAWNEGO}

Przyznanie ochrony wynikającej z prawa do znaku musi zostać nieco zaostrzone w przypadku rejestracji obejmujących element pochodzący z domeny publicznej. Obecny system prawa znaków towarowych w Unii Europejskiej charakteryzuje się elastycznym podejściem do ochrony nazwiska jako znaku towarowego. $Z$ jednej strony ustawodawca unijny nie zastrzegł żadnych dodatkowych obostrzeń względem rejestracji znaków-nazwisk, z drugiej jednak uwzględnił uprawnienie osoby trzeciej fizycznej noszącej zarejestrowane nazwisko do jego używania w obrocie handlowym dopóki jest to użycie znaku w dobrej wierze. Trybunał Sprawiedliwości rozszerzył zakres tego uprawnienia także na jednostki organizacyjne. Przyjęte w porządku prawnym Unii Europejskiej rozwiązanie

32 Wyrok TSUE w sprawie Intel, ibidem, pkt 42. 
prima facie dostatecznie zabezpiecza interes powszechny. Zaletą obowiązującej regulacji jest na pewno możliwość swobodnego dostosowania wykładni do konkretnych okoliczności faktycznych.

Pewne elementy, których ustawodawca unijny nie uwzględnił, powodują jednak, że w praktyce interes powszechny nie jest adekwatnie zabezpieczony. W pierwszej kolejności problemem jest dość wąski zakres kontruprawnienia osoby trzeciej. Konsekwencje tego zjawiska obrazuje przywołany na wstępie przykład walijskiego browaru. Można by dyskutować, czy Boss Brewing rzeczywiście naruszył znaki Hugo Boss, nawet przy uwzględnieniu ich renomowanego charakteru. Spór został rozstrzygnięty na etapie przedsądowym, ale w jego wyniku przedsiębiorca walijski poniósł relatywnie duże nakłady finansowe. Bardziej szczegółowa regulacja zakresu ochrony znaków-nazwisk w przepisach rozporządzenia i dyrektywy byłaby korzystna z perspektywy ochrony interesu powszechnego. Przykładowo można postulować wyraźne wskazanie, że naruszeniem znaku obejmującego nazwisko jest wyłącznie jego pasożytnicze użycie, przy czym zakres ochrony wynikającej ze znaku nie zostałby uszczuplony, bo użycie cudzego znaku nie powodowałoby w tym wypadku naruszenia żadnej z jego funkcji. Proponowane rozwiązanie byłoby też korzystne z punktu widzenia wyrównania szans mniejszych podmiotów działających na rynku.

Podobnie należy ocenić lukę w uregulowaniu relacji pomiędzy znakami renomowanymi a kontruprawnieniem osoby trzeciej opisanym w art. 14 ust. 1 lit. a i ust. 2 dyrektywy 2015/2436 oraz art. 14 ust. 1 lit. a i ust. 2 rozporządzenia 2017/1001. Sprawy, w których znak renomowany jest jednocześnie używanym powszechnie nazwiskiem, mogą być częste. Wyraźne utrzymanie kontruprawnienia osoby trzeciej w takich sytuacjach byłoby dodatkowym wzmocnieniem ochrony interesu powszechnego.

Rejestracja nazwisk jako znaków towarowych jest pozytywnym zjawiskiem. Szeroki zakres ochrony, jaki daje prawo ze znaku, jest elementem wzmocnienia pozycji przedsiębiorcy na rynku. Jest przejawem budowania marki i silnej pozycji na rynku. Nazwisko z samej istoty ma silną zdolność odróżniającą, a tym samym wyraźnie realizuje podstawową funkcję znaku towarowego. Należy jednak mieć na uwadze, że nazwisko pochodzi z domeny publicznej. Rejestracja nazwiska jako znaku nie może prowadzić do nieuzasadnionego zmonopolizowania części rynku. Właściciel znaku-nazwiska powinien korzystać z szerokiego zakresu ochrony, ale wyłącznie przy uwzględnieniu interesu powszechnego. $\mathrm{O}$ ile obowiązujące prawo znaków towarowych Unii Europejskiej przewiduje pewne mechanizmy domeny publicznej, o tyle względem nazwiska nie są one obecnie wyczerpujące. 


\title{
THE SCOPE OF PROTECTION OF A SURNAME AS A REGISTERED TRADEMARK AGAINST PUBLIC DOMAIN INTEREST IN THE EUROPEAN UNION LAW
}

\begin{abstract}
Summary
Surname is a fairly common mark registered as a trademark - and since it is (by default) shared by a number of individuals, it is also a part of public domain. Surname trademarks are a vivid example of a legal dilemma of how to properly balance two conflicting values - public interest and private right. The EU trademark law did provide some means to protect public domain; however, the question arises whether it is enough to provide protection within such a specific area as surname trademarks.
\end{abstract}

Keywords: trademarks, public domain, EU trademark law, generic trademarks, surname trademarks

\section{BIBLIOGRAFIA}

Comedian Joe Lycett changes name to Hugo Boss in swipe at fashion house, https://www.theguardian.com, (dostęp: 2.03.2020).

Dokument nr CDIP/9/INF/5, Study on Misappropriation of Signs, red. M. Seftleben, 14 marca $2012 \mathrm{roku}, \mathrm{http} / / / \mathrm{www} . w i p o . i n t / e d o c s / m d o c s / m d o c s / e n / c d i p \_9 / c d i p \_9$ inf_5.pdf (dostęp: 13.11.2021).

Fashion giant Hugo Boss takes on Boss Brewing in Wales over its name, https://www.walesonline. co.uk (dostęp: 13.04.2020).

Ginsburg J.C., Trademark and Unfair Competition Law: Cases and Materials, Durham 2007.

Promińska U., Wprowadzenie do prawa własności przemystowej, [w:] Nowicka A., Poźniak-Niedzielska M., Promińska U., Żakowska-Henzler H., Prawo własności przemysłowej, red. U. Promińska, Warszawa 2005.

Senftleben M., Public Domain Preservation in EU Trademark Law - A Model for Other Regions?, „The Trademark Reporter” 2013, nr 4.

Welsh brewery changes name of beers after trademark battle with Hugo Boss, https://www.thedrinksbusiness.com (dostęp: 2.03.2020). 